\title{
Inequality and the Labor Market - Theories, opinions, models, and practices of unequal distribution and how they can be justified
}

\author{
Claus Offe
}

Published online: 10 June 2010

(C) Institut für Arbeitsmarkt- und Berufsforschung 2010

\begin{abstract}
The paper provides a multi-disciplinary overview of normative and empirical issues concerning labor markets and inequalities in contemporary capitalist democracies. It begins with a discussion of philosophical controversies in relation to issues of distributive justice. This is followed by a review of peoples' attitudes and opinions, as revealed in surveys and experiments, concerning inequality and fairness. In regard to contributions from economics, the question is discussed whether the relationship between equality/equity and efficiency should be seen as a trade-off. Finally, the thesis is advanced that most of the inequalities (for example in relation to income, job quality, job and income security) are reflected in but not caused by labor markets; instead, the institutional framework in which the labor market is embedded (labor law, education, training, wage determination, social security etc.) is responsible for the (in)equality of outcomes, as are managerial strategies positioning jobs and their holders in firms and other organizations. In his brief conclusion, the author refrains from advocating a normative solution to the issue of distributive fairness; instead, he highlights two axes of controversy that structure the debate.
\end{abstract}

Ungleichheit und der Arbeitsmarkt: Theorien, Meinungen, Modelle und Praktiken der ungleichen Verteilungsergebnisse und wie diese zu rechtfertigen sind

Zusammenfassung Dieser Beitrag bietet einen interdisziplinären Überblick über normative und empirische Fragen

\section{Offe (四)}

Hertie School of Governance,

Quartier 110, Friedrichstraße 180, 10117 Berlin, Germany

e-mail: offe@hertie-school.org bezüglich der Arbeitsmärkte und Ungleichheiten in modernen kapitalistischen Demokratien. Anfangs werden philosophische Kontroversen über Fragen der Verteilungsgerechtigkeit betrachtet. Anschließend werden die Einstellungen und Meinungen „normaler“ Menschen bezüglich der Ungleichheit und der Gerechtigkeit, wie in Umfragen und Experimenten erkennbar, zusammengefasst. Was ökonomische Beiträge betrifft, wird die Frage diskutiert, ob es gilt, die Gleichheit und die Effizienz als in einer Trade-OffBeziehung zueinander stehend zu verstehen. Schließlich wird die These aufgestellt, die besagt, dass sich die meisten Ungleichheiten (bezüglich Einkommen, Arbeitsbedingungen und Arbeitsplatz- und Einkommenssicherheit) zwar in den Arbeitsmärkten widerspiegeln, aber nicht von ihnen verursacht werden; stattdessen ist die (Un-)Gleichheit der Ergebnisse dem institutionellen Rahmen, in dem der Arbeitsmarkt eingebettet ist (Arbeitsrecht, Bildung, Ausbildung, Lohnfestsetzung, soziale Sicherheit usw.), zuzuschreiben und auch den betriebswirtschaftlichen Strategien, die Arbeitsplätze und deren Inhaber in Firmen und anderen Organisationen zu positionieren. In seinem kurzen Schlusswort verzichtet der Autor darauf, eine normative Lösung für das Problem der Verteilungsgerechtigkeit zu befürworten; stattdessen hebt er die zwei Achsen der Kontroverse hervor, die diese Debatte strukturieren.

\section{Introduction}

All societies face the dual challenge of solving two particular problems in a consistent and reliable way. The first problem is that of production, i.e., how and by whom are factors of production combined, and what division of labor is adopted, in order to generate and increase the overall output. The other is the problem of distribution: After produc- 
tion has taken place, its fruits must be allocated to those who have participated in the process, as well as others. Only the latter problem is what interests us here. There are, however, two evident links between the solutions of our two problems. First, and at least in the long run, the volume of production constrains the volume of what can be distributed. More interestingly, the pattern of distribution (say between workers and investors, or consumption and savings) has implications for the volume of future cycles of production.

Any nearly complete normative theory of what distributive justice demands in terms of equality and to what extent inequalities must be accepted as justified will have to answer at least three questions. The first concerns the moral duties (e.g., the due recognition of need, desert, or entitlement) or/and desirable consequences (such as efficiency, well-being, socio-economic security) that support the demand for or constitute exceptions from equality. Secondly, the question needs to be answered that was famously posed by Sen (1980): "Equality of What?", with the alternative philosophical answers being "resources" (or "opportunities"), "welfare", and "capabilities". The answers that policy-makers are concerned with are equalisanda such as income, wealth, housing, access to the labor market and jobs, life expectancy, social protection, access to services (education, health, police protection) and infrastructure such as public transportation. In a different conceptualization, equality may mean the equal opportunity of persons to pursue freely chosen life plans. I'll briefly return below to the debate that Sen's work has triggered.

Thirdly, the universe of people must also be defined across whom valued resources are to be distributed in a justifiable manner. Most authors do not address this issue at all, implying that the answer is the citizenry of the nation state, the latter fulfilling the demands of justice through redistributive tax and other policies. But even if this (very limited) understanding of the scope of (in)equality is accepted, ambiguities remain as to who is to be equalized to whom. To illustrate, consider an example from pension policy. Here, the question is: Which universe do we want to equalize across? The answer can be, first, that all pensioners should receive the same (i.e., a flat rate) pension; second, that, in a longitudinal perspective, levels of individual transfers should mirror the relative income position that the pensioner has occupied previously during his or her active years, thus equalizing, in line with the "Bismarckian" ideal, relative status over biographical time slices; third, it can mean that the cohorts of present pensioners should be allowed to partake in the economic gains made by the presently active cohorts, as in any "dynamic", or indexed, pension system with regular adjustments of pensions to increases of current real wages, a method that equalizes income gains from growth across the entire adult population. While all three of these design options are related to some understanding of "equality", evidently not all of them are mutually compatible.

Issues of social and economic inequality are central to many debates in the social sciences. In my overview of some current problems, I shall proceed as follows. First, I wish to look at some of the recent normative debates among egalitarians and others on what justice requires concerning the distribution of resources. Apart from philosophical principles, there are also opinions, beliefs, and social norms, often strongly held, of ordinary citizens concerning the (un)desirability of (un)equal patterns of distribution; these beliefs and opinions are determined by a wide variety of causal factors. In the second part of the paper, I briefly discuss the question of to what extent the labor market, as opposed to the institutional arrangements in which it is embedded and which are essentially of a political nature (the educational system, by the political regime of taxation and subsidies, etc.) determine observable patterns of income and other inequalities. In the third part, I am going to address the question of how firms and other work organizations structure and justify inequalities among the holders of jobs and positions.

\section{Inequalities: Philosophical principles, social norms, and economic models}

Most people living in capitalist market societies depend, directly and indirectly and at least for major periods of their adult life, on an income that results from their performance of waged labor. Wages and other (un)desirable aspects of employed labor differ substantially, thus generating a great deal of inequality of earnings, standards of living, and opportunities. These differences give rise to the question: Why should "I", the low income earner, content myself with the inferior position I have compared to "you", the well-to-do employee. Questions of this type call for the justification of (in)equalities. Justifications must either explain, in normative terms that are acceptable even to the less well-off, why a given pattern of distribution is legitimate; or, alternatively, answers must point to an alternative and more justifiable design of distribution that is deemed superior, to all sides involved, compared to the status quo.

In this section, I review some of the philosophical principles of distributive justice that play a role in asking and answering this kind of question. One demand that has been made in the history of leftist egalitarian ideas is the demand to endow every adult person in society with a "right to work", as was de facto implemented in the state socialist societies of the Comecon. There are two reasons why this idea is a clear nonstarter. First, a "right to work" and, by implication, a right to an adequate income derived from that work, presupposes the competence of some ad- 
ministration or planning agency to authoritatively allocate workers to jobs, as well as incomes to workers, thus solving the dual problem of production/distribution by virtually suspending market mechanisms. The authoritarianism of such administrative placement of labor can hardly be defended in normative terms. Secondly, it also cannot be defended in economic terms, as incentives governing labor mobility and work effort would largely be eliminated, thus generating huge inefficiencies. ${ }^{1}$ As the pseudo-solution of authoritarian egalitarianism must therefore be dropped from the list of respectable options, I wish to sketch and briefly discuss four lines of philosophical arguments which can be located, somewhat schematically, on a continuum that ranges from libertarian/individualist positions at one extreme to communitarian views, at the other. In between the two are liberal egalitarian theories of distributive justice (largely deriving from Rawlsian maximin ideas), as well as the capability approach to distributive justice introduced by Armatya Sen.

For theorists of libertarian individualism, such as Nozick (1974), every distributional outcome is just that which is consistent with the two rules of self-ownership and freedom of contract. The libertarian message is that people do not owe each other any redistributive transfers, and that therefore the limited amount of taxation that cannot be avoided should not be used for redistributive purposes. The only thing that needs to be equalized is (property) rights. Thus, the most moderate definition is the equation of equality with a universalist and non-discriminatory regime of individual rights, such as property rights - regardless of the presence or absence of the resources that are needed in order to actually make use of those rights. Yet it is obvious that people need resources in order to make use of those rights - otherwise rights remain empty shells and purely nominal. Property rights are the rights of the owners of property; labor rights apply only to those who actually have a job; and even educational rights of youths presuppose that parents permit, support, and encourage attendance of secondary schools (which sometimes is not the case with girls coming from migrant families). The Achilles heel of the libertarian argument is its failure to take into account the presence of unequal conditions that determine the use people can make of nominally equal rights. Even if the non-discrimination criterion of access to rights were strictly observed, this would not neutralize the positive discrimination favoring those who happen to be endowed with the material resources needed to make use of those rights.

\footnotetext{
${ }^{1}$ Note, however, that these normative and functional objections do not apply to left-libertarian proposals to create not a "right to work", but a citizenship right to a ("basic") income. For a recent contribution to this debate see Offe (2009).
}

The liberal egalitarian counter-position focuses on exactly those "conditions", or "circumstances". Its basic operation consists of conceptually splitting up the causes of socio-economic success: "conditions" vs. "efforts", "ambitions", or "choices". It shares with the libertarian view its focus on divisible private goods yet uses a different principle of distributive justice, as it insists on compensating people for their undeserved "bad luck" (such as genetically achieved poor talent, family background, physical handicaps, but also position in the class structure - everything that is not a matter of the choice of an individual in question). The key notion is the neutralization of individual misfortune through a redistribution of some of the ("undeserved") resources of the lucky ones. What is to be equalized, according to "luck egalitarian" principles, is fortune (Cohen 2008; Dworkin 2000, ch. 1 and 2; Roemer 1998). To be sure, once conditions and endowments are equalized in this way, there will be no equality of welfare outcomes, but just equality of opportunity - the opportunity of individuals, that is, to make responsible choices in exercising ambitions and efforts so as to pursue their "option luck" in a society which distributes resources and generates inequalities in purely "ambitionsensitive" ways.

The neat conceptual distinction between unchosen conditions (patterns of discrimination prevailing in a given society, genetically inherited talents or handicaps, family background, social networks) and chosen modes of action (ambitions, efforts) can fail to make practical sense in view of the following three complications: First, there may be strong empirical indications that the conceptual dualism of condition vs. ambition breaks down when conditions themselves can be shown to interfere with and discourage the exercising of ambition and effort. As Halliday argues, there may be an "interaction between circumstance and effort". Second, society may be unwilling, and for very respectable reasons so, to reward effort alone according to a logic of desert - rather that rewarding merit, which is the joint product of circumstances/conditions and efforts/ambitions (Halliday 2008, p. 8 f.). ${ }^{2}$ For instance, a medical student who made the same or even greater effort, compared to her fellow students, to study but eventually failed the exam due to inferior conditions is hardly acceptable as a practitioner of surgery. Rather, she will be held accountable for that failure (by having to bear the cost of missing a medical career) without being, arguably, responsible for it. Inversely, someone who has failed to make a minimal effort (let us assume: exclusively due to his own weakness of will and ambition) can still not be excluded from receiving some minimal kind of transfers,

\footnotetext{
2 "As much as a particularly short person exerts an incredible degree of effort to play basketball, realizing [his] ambition to play NBA basketball is unlikely" (Halliday 2008, p. 10).
} 
or means of subsistence, under any regime of welfare or social assistance. Third, not all circumstances need to be envisioned as being of the fateful kind that the dichotomy suggests, as in the case of a person who is born with severe physical handicaps. Pierik and Robeyns (2007) criticize Dworkin for reifying "conditions": "Dworkin focuses solely on the natural sources of inequality. ... He ignores that inequalities between handicapped and non-handicapped are as much the result of structures and mechanisms in society as of the physical handicap itself." In the case of race and gender, the authors claim, it is virtually only due to those "social mechanisms" that congenital differences become a matter of "morally relevant inequalities". The presence of what the authors aptly call "societal endowments" constitutes non-intentional selectivities, in addition to "natural" ones. These societal "endowments" include, for instance, widely shared "cognitive gender schemes [which lead] to different treatment of men and women in the labor market, without necessarily being caused by overt or intentional discrimination" (ibid., p. 21).

Liberal egalitarians, as we have seen, draw the line between unproblematic choice-based inequalities and objectionable condition-based ones, with the latter to be neutralized by political means. They will be neutralized once cases of brute luck are being compensated for so that they lose their fateful negative impact. In order to equalize opportunity, we might also think of such widely used mechanisms as anti-discrimination laws (including a reversal of the burden of proof in cases of alleged discrimination), affirmative action, reverse discrimination, and quota systems. These institutional devices may work well in a synchronous and ex ante perspective, i.e., when people belonging to one and the same age cohort are channeled through educational and recruitment procedures. This does not, however, preclude the possibility that in an ex post and diachronic perspective mechanisms of status inheritance persist which are not due to anyone's discriminatory decisions, but to anonymous mechanisms of social selectivity, such as the massive failure of the educational system to compensate for socially inherited handicaps and disadvantages. There can be discrimination, that is, without anyone deliberately and demonstrably discriminating; arguably, even the vast majority of cases of discrimination, or of "morally arbitrary" determinants of status, privilege, and exclusion, follow this non-intentional pattern. While negative discrimination (e.g., against women and ethnic minorities) can be controlled by anti-discrimination practices, does the same also apply to cases of "fortunate" luck? In the GDR and other state-socialist countries, access to university education was, at least at the level of ideological proclamations, made more difficult for sons and daughters of academics than for those of nonacademics. It is hard to imagine that anyone would be willing to advocate this neutralization of positive discrimination and to pay the moral (as well as economic) price for this practice. The question is, however, whether the project of "equality of opportunity" can be advanced without it.

There thus remain many open questions and contested answers with this liberal egalitarian approach to purely "ambition sensitive" distributional justice. (cf. Anderson 1999) Can we really draw a sharp line between what is due to "(un)lucky conditions" and what is due to voluntary efforts, given the fact that losers will tend to attribute to circumstance what winners are likely to attribute to choice? ${ }^{3}$ Isn't there an interaction between the two such that some adverse conditions cannot be hindered to discourage the unfolding of ambitions and efforts - the latter being entirely conceived of, even by a strong egalitarian such as Roemer (1998, p. 24), as being entirely a matter of individual responsibility? Are conditions only "objective" ones (such as physical handicaps) or do they also include the (arguably less objective) condition of "having expensive tastes"? Can conditions which are due to brute luck actually be fully neutralized through redistribution of income and access? If what is to be rewarded is "desert" alone (which is by definition due to choice and responsible effort), rather than "merit" (which is defined as a joint outcome of effort and [un]fortunate conditions), we need to deal, in terms of just rewards, with the difficult mixed case where A shows greater desert than B yet B, due to her inherited talents, greater merit than A (Halliday 2008, p. 10). Will society be prepared to tax away the rent on "talent", as talent clearly belongs to the realm of conditions and undeserved circumstances?

Other theories of distributive justice depart from the individualist premises of both libertarian and egalitarian doctrines. Here, what is to be distributed and equalized are neither resource inputs nor welfare outcomes, but substantive freedom. One of the best known and most widely discussed is "capability egalitarianism" as proposed by Sen (1992). It starts with the claim that individuals should have the same real or substantive freedom to lead the life that they have reason to value. Capabilities determine the extent to which persons can achieve what they wish to do and be ("functionings") according to their preferred life plans. For the achievement of this freedom, they depend upon a set of collective arrangements which provide them with the appropriate opportunities. These arrangements protect citizens from all kinds of oppression and allow them to perform their role as equal and respected citizens. These capability-providing arrangements include basic civil, social, and political rights, the access to education, information, transportation, legal protection, etc. - all of

\footnotetext{
3 "Public institutions cannot effectively track the choice/circumstances distinction. ... We often cannot distinguish the voluntarily and the involuntarily disadvantaged" (Kymlicka 2006, p. 20 f.).
} 
which are less a matter of fair rewards for efforts made by individuals rather than a matter of democratic political institutions and the public policies they generate. Once these institutions, policies, and arrangements are in place, the inequality of individual resources that are contingent upon the labor contract, labor market, or work effort may even become a secondary consideration: "Once all citizens enjoy a decent set of freedoms, sufficient for functioning as an equal in society, income inequalities beyond that point do not seem so troubling in themselves" (Anderson 1999 , p. 326). In other words, once everyone in a society enjoys full citizenship rights and related entitlements (including education, vocational training, labor market access, and rights of association), the remaining income inequalities need no longer be of major concern in terms of distributive justice. Moreover, a policy of building capabilities and freedoms to function as an equal citizen would appear to favor those most who, in the absence of such capability-enhancing arrangements, are most likely to become victims of oppression and are least likely to achieve the "functioning" of an equal and respected citizen by their own means.

Capability egalitarianism is distributive rather than redistributive: it allocates opportunities to some without necessarily taking resources away from others. For instance, if people are provided with rights and public goods, as well as the institutional means to make use of these rights and have them enforced in case of conflict, this does not imply that others have fewer rights or shares of public goods. (Pierik and Robeyns 2007, p. 14) Capability enhancement is a targeted policy of providing those with the ability to "function" who do not yet have (enough of) it. It is designed to provide a common floor, or level playing field for all. It is also designed to leave open which life plans people want to pursue once they are endowed with capabilities; this is a matter they have to decide, responsibly and on the basis of reasons. In that sense, the "underspecification" of the capabilities to be enhanced is not a shortcoming of the concept, but a strength: the objective of improving someone's capabilities is certainly more universalist, both across people and across competing life plans, than the notion of equal opportunity and "employability" that is predominantly focused on the labor market.

Finally, let us briefly consider an author who is to be located at the non-individualist end of our continuum. Following Miller (1999), Kymlicka (2006) draws a distinction here between individualistic theories of distributive justice which scrutinize justifications for inter-individual inequalities (such as differences of ambition) and a more "social" notion of equality which aims at the egalitarian structuration of "the quality and texture of social relations" (ibid., p. 25). The former has its roots in the liberal tradition, the latter in socialist and communitarian ones. $\mathrm{He}$ suggests that the liberal egalitarian discourse on distributive justice has generated a frame of reasoning that is deeply destructive of social cohesion and solidarity as the very analytical distinction between "conditions" and "choices" spreads distrust and suspicion among citizens. The liberal egalitarian approach, as we have seen, calls for redistributive compensation of inter-individual income differences if and to the extent that they are caused by "conditions", while holding individuals accountable for lack of effort and imprudent choices. There are two dimensions of conflict here: structural privilege vs. deprivation in the dimension of "conditions" and hard-work effort-making vs. laziness and indolence in the dimension of "choices". But there is also a meta-conflict as to which of these two dimensions is claimed as being responsible in any given case of inter-individual inequality of resources. The rich will claim that their wealth is well-deserved (through hard work and prudent choices, which should not be taxed in order to preserve incentives), while the inferior income of the poor must, in the eyes of the rich, be attributed not to conditions but to the choices of the poor; therefore, they do not deserve compensation out of general taxes (that the talented rich and the hard-working would have to pay), but should be left to their fully deserved inferior status. The poor, needless to say, have every reason to see it the other way. As there is no agent that is able to judge with any authority which of the two opposing views of distributive justice is right, we are left with a lingering conflict that is familiar from, for instance, political debates on labor market policies of "workfare" and "activation". The net effect of this politicized conflict over distributional justice is, as Kymlicka rightly observes, a taste that is being cultivated for tightening other people's belts. A "culture of distrust and disrespect" (ibid., p. 32) spreads among citizens that corrodes "norms of equal respect" (ibid., p. 24) and "poisons relations between the poor and other members of society" (ibid., p. 26), thereby causing "pernicious social consequences of material inequalities" (ibid., p. 27).

What is the suggested way out? In the absence of a valid and uncontested criterion of what is due to condition and what to choice, the author turns to a combination of two solutions. One is an appeal to "civic virtue" (ibid., p. 22) and the assertion that "institutions can and should promote a certain ethos of justice" (ibid., p. 21) and "inculcate an ethos of good citizenship" (ibid., p. 24) that would lead all citizens to critically question not the presumed entitlements of others, but primarily "the claims for resources we make" by probing "the moral defensibility of our own claims to resources" (ibid., p. 23) [my emphasis, C. O.]. Kymlicka believes that this attitude could restore and maintain the spirit of civility, solidarity, community, and the vision of a "society of social equals" (Kymlicka 2006, p. 25) that is governed by "norms of equal respect" (ibid., p. 24). The other ingredi- 
ent of the proposed solution is a certain agnosticism concerning the fairness of individualized inequalities. "So long as people's shares of resources do not fall below the minimum floor [concerning the satisfaction of basic needs] or rise above the ceiling", people should be dissuaded from engaging into "struggles over distribution and redistribution" (ibid., p. 29) which cannot be settled anyway in morally valid ways. Yet there seems to be an aporetic inconsistency in this two-tiered solution to the problem of distributive justice that the author himself acknowledges. For in order for citizens to self-critically test the "moral defensibility of our own claims" they need a yardstick the availability of which, however, is convincingly denied by the second component of the proposed solution, agnosticism. "It is not clear", Kymlicka writes, "what ... criteria ... citizens should use in judging the justice of their claims" (ibid., p. 29).

After this brief review of philosophical principles addressing questions of distributive justice, we turn, even more briefly, to the sociological question concerning the strength, distribution, and determinants of egalitarian social norms. Social norms are partly held and acted upon reflectively, i.e., depending on the relative position agents see themselves as holding. Thus, people whom we find advocating "more" equality can do so for quite diverse motivations. One of these motivations is the upward-looking and often envy-driven desire that nobody should receive much more than we, the "ordinary people". There are other ("Rawlsian") egalitarians who are motivated primarily by compassion and a downward-looking concern for those who have much less, in terms of material resources and opportunities, than we, the (above) average people.

How likely is it that individuals actually practice - rather than merely agree to and proclaim - egalitarian social norms? Distribution experiments, where persons must make a choice between more efficient and more egalitarian courses of action, are one method of answering this question (Fehr et al. 2006). One finding is that professional self-selection and socialization into norms of efficiency play a major role in shaping such choices: Students of economics and business administration show significantly lower inclinations to act in "inequality averse" ways and are much more likely than students of other disciplines to sacrifice equality for efficiency in their choices. Alesina and Giuliano (2009) analyze survey data on "preferences for redistribution" and the determinants of such preferences. The authors show that individuals' attributes (income level, gender, in the US also race, religion) as well as country and region (US vs. Europe) are all important variables that determine the intensity of preferences for redistribution. For instance, "the richer you are, the less you favor redistribution" (ibid., p. 13) and, unsurprisingly, "unemployed people are more favorable to redistribution" (ibid., p. 14). Yet self-interest is not the only determinant. The authors suggest that the argument plays a role that redistribution will facilitate the participation of its beneficiaries in successful secondary education, the positive externalities of which will benefit "all of us", as will the reduction of crime that is perceived to result from poverty. Others favor redistribution for its own sake because they follow their notion of some "ideal profile of inequality in society" (ibid., p. 16) and are willing to sacrifice some efficiency, apparently in exchange for the satisfaction derived from the sense of living in a just society. There appear to be national cultures and historical traditions within countries which favor or disfavor redistributive measures, most clearly in the post-Communist countries of Central Eastern Europe which still are the "most pro-government redistribution" (ibid., p. 21). Finally, people hold clear beliefs about whether "luck" or "effort" is responsible for the economic success or failure of individuals; "believing that luck is more important than work as a driver of success is strongly associated with a taste for redistribution" (ibid., p. 22).

After social philosophy and empirical sociology, let us finally consider what some economists have to say about the effects of inequality. The matter can conveniently be captured in dialogue form. In this dialogue, economists will typically frame the relationship between equality and efficiency as a trade-off. Their null-hypothesis tends to insist that gains in (mandatory, government-sponsored) redistribution (as opposed to redistribution via voluntary donations) will necessarily lead to losses in efficiency. In response, advocates of redistribution among economists focus on cases where this is not the case, such as when redistribution is shown to contribute to an overall increase of human capital (through redistributive educational and health services) and/or to enhance productivity by helping to avoid the economic costs of social and political conflict and to foster social peace and integration. Yet their opponents, apart from downplaying the potential costs of social conflict, can point to the efficiency losses that are, in their view, doubtlessly caused by redistribution. These losses are of two kinds. First, investors have less to invest as parts of their profit are taxed away for egalitarian and welfare state purposes, thus diminishing expansion and growth. Second, the recipients of redistributive transfers are "disincentivized" and thus relieved from the pressure of having to seek jobs as intensely and work as hard as they otherwise would have to in order to escape from their undesirable income situation. Also, critics of redistribution will try to show that the efficiency gains derived from inequality will ultimately "trickle down", so to favor, in the long run and in a dynamic perspective, even those who, for the time being, have lost in the distributional game. At this point in our stylized dialogue, either of two things can happen. First, arguments from justice are being introduced into the debate, claiming that increments of efficiency have the property of benefitting some while damaging, certainly in 
the short and medium term, others (e.g., people being dismissed from their jobs), with the consequence that the former can be held morally liable to pay compensation to the latter out of the non-universal efficiency gains they realize (e.g., as pioneers of labor-saving process innovations). Second, an empirical demonstration can be attempted to the effect that at least some redistributive policies are not detrimental, but positively conducive to efficiency increases (in addition, that is, to the human capital and social peace arguments I mentioned earlier).

Let me conclude this brief section on the economics of inequality by drawing, for illustrative purposes, upon two studies which pursue the latter alternative. First, Galbraith et al. (1999) find that, contrary to the alleged incentive effect of income inequality, there is a positive correlation, across and within European countries, between inequality and unemployment. While it is less surprising that unemployment causes inequality, the authors argue that the causal link points in the opposite direction: In highly unequal wage structures, the low pay of low productivity jobs leads workers to leave them in the hope of finding better-paying ones: "inequality reduces the subjective opportunity cost of leaving a low-productivity job" (ibid., p. 39). Low wages make them overly risk-prone, ignoring the slim chance of actually finding better paying jobs. As a consequence, they end up unemployed. This unfortunate outcome could have been prevented, or so the policy implication of this analysis suggests, if wages for low productivity jobs were topped-up by tax-financed subsidies of the Earned Income Tax Credit (EITC) type (ibid., p. 51).

Another doubt concerning the efficiency enhancing impact of inequality for labor markets is raised by a group of Scandinavian economists (Jäntti et al. 2006). The authors compare rates of inter-generational earnings mobility in the US, Great Britain, and four Nordic countries. The findings indicate that relatively inegalitarian income distributions in the two Anglo countries do not contribute to, but significantly hinder inter-generational earnings mobility. Family background and other "luck" factors play a bigger role in the US than in the European cases, as in the former "sons of poorest fathers will remain in the lowest earnings quintile" and, conversely, there exists comparatively "low longdistance mobility from the top" in the US (ibid., p. 27). This finding about the high inter-generational status persistence in the Anglo countries, and particularly in the US, leads the authors to conclude that the proverbial "American dream" of unlimited opportunity for upward mobility is in fact much better realized in relatively egalitarian Scandinavia than it is in the US itself (ibid., p. 2). In terms of the efficiency of the allocation of labor this may be interpreted as showing that the second generation "talent" which the more egalitarian Scandinavian countries allow to relatively freely move up (and down) the earnings ladder is trapped, or gets stuck, in the more rigid structure of earnings in the US. Again, inequality turns out to be inefficient in its consequences.

\section{Does the labor market cause inequalities?}

Market outcomes can be explained and they can be justified. In standard economic theory, justification draws upon the ultimate value of freedom. That is to say, as buyers cannot be forced by sellers (or vice versa) to enter into the transaction, this transaction is deemed to be entirely voluntary, thus preserving the freedom of either side. If the transaction were contrary to their free will, they could always refrain or exit from it. As far as the explanation is concerned, there is the issue of whether the interplay of free wills alone can explain prices and distributional outcomes. Chances are that those who seemingly exercise their free will do in fact have no choice other than to buy/sell the way they do. If that is found not to be the case (e.g., in cases of supply side or demand side monopolies or asymmetrical dependencies and power relations resulting from them), this finding will have implications for the validity of the justification of market outcomes. It is therefore of great political and moral interest to find out whether income differentials - be it the functional ones between owners of factors, be it interpersonal ones among categories of working people - can actually be explained in ways that effectively contribute to their justification.

In this section I shall suggest that labor markets, far from being the location of voluntary exchange, are basically institutional arrangements that register and enforce inequalities the origin of which are to be located outside the market transaction itself. Perhaps labor markets in all kinds of capitalist welfare states can best be described as "sorting machines" which function as catalysts of patterns of distribution and inequality that are already in place before, as it were, the market transaction begins and the labor contract is concluded. Labor markets are deeply embedded into a framework of public policies, as well as institutions created by such policies, which to a large extent assign the respective opportunities and distributional positions to actors as they encounter each other on the supply and demand sides of the labor market. Both sides are institutionally positioned (enabled or constrained) and endowed with all kinds of privileges, licenses, status rights, power positions, etc. before they become partners in contract. These pre-contractual conditions apply, for instance, to the shape of the wage scale that prevails in a sector of industry or location; the professional and vocational specification of the units of labor to be traded (which define, for instance, what an "electrician" is); institutional mechanisms of wage determination and the power of collective actors on either side of the market; the role 
of seniority in wage determination; the taxes and benefits that apply to labor, including minimum wages and employment or wage subsidies; the structure of family allowances and benefits; the facilities for education, vocational training, and other forms of skill acquisition and certification available ${ }^{4}$ the levels of demand and supply for labor as determined by macro-economic policies and public sector employment; the extent to which ethnic, gender, and age differences determine the division of labor, access to jobs, and remuneration; the "luck" factors of family background and the presence/absence of social networks on which market participants can rely; the regime that regulates the temporal structure of the labor process, including rules applying to job and income security; the ease with which transitions from the status of employed labor to self-employment can be made, as well as the transition to unemployment or retirement; the overall cost and its distribution of social security and occupational benefits; the opportunities for labor-saving technical and organizational change employers in a particular sector or company enjoy; institutions and programs of active labor market policies; and many more. Paraphrasing Emile Durkheim, one might say that these and other parameters form a non-contractual and non-negotiable framework of the labor contract.

Virtually the only thing that can arguably be causally attributed to the labor market itself, rather than the multiple institutional arrangements in which it is embedded, is the volume and kind of people that are admitted to the status of being employed and the sorting out of those being either dismissed from jobs or denied access under given institutional and macro-economic conditions. Yet even this proposition is debatable at the macro level. For there are two equilibria that govern the dynamics of labor markets. First, the quantitative equilibrium between labor supply (the total of individuals in employment plus those currently seeking employment) and the demand for labor. Second, the equilibrium between wages earned, as well as other forms of income received, by households and the needs these households seek to satisfy. Both of these (dis)equilibria are massively shaped by political institutions and programs. As to the second equilibrium, it will be affected by welfare, EITC, and other transfer programs, including those of family policy and training and continuing education programs. These institutions and programs have indirect effects upon the first equilibrium, i.e., on the number of people showing up on the supply side of the labor market. The first equilibrium is also directly affected by a number of public policies, for instance by the migration regime and the definition of the retirement age.

\footnotetext{
4 As "normal" markets reflect relative scarcities in prices, the scarcities in labor markets can be seen as artefacts of the educational system, license requirements, arrangements of social closure, etc.
}

These considerations allow for the interpretation that it is not the labor market as an anonymous mechanism of free transactions, but the set of politically installed (and hence politically contingent) institutional frameworks which determines the shape of distributional outcomes. If these outcomes are to be justified, the burden of justification cannot rest with the individuals and their freedom to enter or not to enter into contracts with each other, as is the case with markets for vegetables. Instead, this burden must be shouldered by political elites and according to democratic rules by which they can be held accountable, as it is them who bear the responsibility for (re)designing the institutional framework, be it at the national or the international/European level, within which the demand, supply, and price of labor is being shaped. If the gap between the lowest and the highest wages is ever-widening, as is the case with most countries of the OECD world, thereby violating prevailing norms of social equality as well as policy goals of "social cohesion", it is within the political arena where responsibilities must be attributed and potential remedies sought.

The British New Economics Foundation (2009) has published a study with estimates on the relationship between earnings of six occupational groups (ranging from "bankers" to "waste recycling workers") and what the authors term the "social value" or "worth" of those who perform these functions. They calculate ratios that indicate how much net worth (i.e., the balance of negative and positive externalities) a typical practitioner of these occupations generates per one unit of pay, measured in British pounds. While estimates of "social worth" involve potentially contested evaluations and quantifications of positive and negative externalities that enter into an overall social utility function, the results of these estimates are nevertheless striking and suggestive due to their orders of magnitude. For instance, "for every pound [childcare workers] are paid, [they] generate between 7 and 9.5 pounds worth to society", while advertising executives, earning up to one thousand times higher incomes, are estimated to "destroy 11 pounds of value for every pound of value they generate". The greatest social productivity is estimated to be connected with the work of hospital cleaners and waste recycling workers, both of which are near the bottom of the overall income scale.

\section{Explaining and justifying inequalities within firms and other formal organizations}

As we have seen in the first section of this paper, egalitarian theories address themselves, at least implicitly, to the state as the agent of equalization. Through its policies of taxation, redistribution, infrastructural capability building, and not least the judicial enforcement of equal rights, it is 
the state that can provide for the implementation of what normative theorists describe as distributional fairness. The state also establishes, as I have shown in the second section, the vast institutional framework in which the labor market is embedded. Yet distributional (in)equalities are not the only generated direct and indirect consequences of state action. We therefore now turn to a discussion of the inequalities that are generated within work organizations, both private firms and public administrations, and their internal "labor markets". These inequalities are constituted as the joint outcome of managerial decisions and the regulatory constraints individual and collective labor law imposes on managerial discretion. These inequalities apply to the three dimensions of monetary compensations (wages, salaries, benefits), intrinsic (positive and negative) job characteristics (including such items as autonomy, authority, opportunities for skill acquisition), and job or employment security. These dimensions can relate to each other as cumulative (e.g., when the most poorly paid jobs are the intrinsically least attractive) or as trade-offs (e.g., lower pay in exchange for greater job security as a deal made in concession bargaining). Work organizations such as firms are involved in a continuous process of ranking and positioning employees into complex hierarchies that are made up by these three dimensions. In the process, workers and jobs are inserted and vertically ranked through managerial decisions which in most cases cannot be derived from data given by the external labor market. ${ }^{5}$

How do we explain the hierarchies and inequalities thus established through managerial decision? Note that what needs to be explained is both the shape of the wage scale (stretched vs. compressed) and the position on that scale that is being assigned to individuals or categories of employees. Limiting my attention here to the latter issue, I find the economists' standard answer that workers are being rewarded according to their "marginal product" entirely unhelpful. How should managers/entrepreneurs be able to know, even to predict at the start of an employment relation, what a worker's "marginal product" is, given the fact that total output of a firm can rarely be disaggregated and linked to individual contributions? Rather, it must be seen as the outcome of a complex pattern of ongoing cooperation of many contributors of diverse ranks and positions. What is needed here, instead, is some managerial metric of proportionality that links a worker's characteristics, as well as job characteristics, to a particular hierarchical position. Ideally, such a "meritocratic" metric would not only explain the

\footnotetext{
${ }^{5}$ They can be thus derived if an employee has the option to obtain a "better" package from an alternative employer, perhaps prompting the management to promote him/her to a higher position; or if management perceives that workers who quit can be easily replaced through new recruits from the external labor market, therefore denying them a pay rise. I assume here that such "externally dictated" decisions are the exception rather than the rule in the everyday operation of work organizations.
}

resulting hierarchical structure but also justify the resulting pattern of intra-organizational inequality as legitimate, and the inferior as well as superior positions of individuals as somehow "appropriate" and "well deserved".

The theoretical claim I try to support in the remainder of this essay is twofold. First, not all organizational inequalities can be explained, i.e., accounted for in a non-tautological way, as following at all from some logic of managerial rationality. Second, to the limited extent they can, these explanations of how organizational inequalities come into being do not yield justificatory arguments, and issues of distributional fairness and "just" inequalities within work organizations remain essentially contested. (Offe 1976)

If status rights - remuneration, intrinsic job quality, security - are the main components of the dependent variable, what are the components of the independent variable? Leaving aside the important question of how the remuneration of investors, entrepreneurs, and managers is to be explained and justified (standard answers refer to the need to compensate them for refraining from consumption, to dividends being a premium for the risks they undergo, or to rewards for the performance of highly skilled and demanding entrepreneurial tasks), I concentrate on the remuneration and other aspects of the organizational status of non-managerial employees. The determinants that enter into the negotiation and definition of their hierarchical status include skills, experience, seniority, gender, time, and "responsibility". Let me briefly try to disentangle some of the ambiguities inherent in this set of independent variables.

Common economic thinking, as well as much of the everyday debates and polemics over social and labor market policies, rests on the assumption (and attempted justification) that the rewards (wages, job security) workers receive somehow reflect their productivity. In addition, it might be stated that the productivity of a worker also, in addition to her skills and efforts, reflects the technical and organizational configuration of the job she performs. Productivity, in other words, is not a feature of persons alone; it is also a feature that owners, investors, and managers have determined when creating a job. Through designing jobs, investors/managers make workers more or less productive. For instance, the labor of room cleaners suddenly became much more productive after the invention and diffusion of the vacuum cleaner. It follows that interpersonal differences of labor productivity can only be assessed if we were to keep technology and organization constant which amounts to a truly heroic assumption which negates the "job design" component of productivity. It further follows that under conditions of labor supply massively and chronically exceeding labor demand, it is at least an open (and arguably even unanswerable) question whether the spread of a low wage sector is due to the qualitatively low marginal productivity and lack of human capital of 
those working in that sector or whether the phenomenon can be better explained by the wage-depressing quantitative effect of job-seekers (whatever their skills and efforts) exceeding the volume of available jobs. Where conditions such as these prevail, skills, work effort, ambition, and responsibility as the putative fair generators of relative status in work organizations not only fail to play a plausible role in the explanation/justification of status differentials, instead, the opposite direction of causation may prevail: Not the lack of human capital causes either unemployment or low-wage employment, but the condition and expectation of labor market precariousness leads to the waste and degeneration of skills, while their acquisition is discouraged and opportunities to make "work efforts" are foreclosed or de-motivated by the evident absence of credible access routes to the "first" labor market in which meritocratic fairness is supposed to rule.

What workers are remunerated for (and actually claim proportionate remuneration for) is not just a) their productive contribution to the cooperative production of marketable goods and services, or the utility of labor to the firm, but also b) the intrinsic labor disutility they experience in the process and for which they claim compensation. Wages compensate workers for an uncertain mix of either of these aspects, with the question remaining hard to decide whether workers earn their remuneration by what they do (contribute) or by what they endure while doing it. Everyday evidence shows that there is no co-variation between these two variables. That is to say, jobs with relatively low skill requirements and low productivity are often associated with intrinsically highly undesirable characteristics (repetitiveness, physical stress, exhaustion, low autonomy, no authority, no opportunities for skill acquisition etc.), while others combine high skills requirements with high productivity and high intrinsic satisfaction. In such "good" jobs, not only negative features (health and accident hazards, dirty work environment, tedious routines) are absent, but the intrinsic valuation of "interesting" challenges is typically greater than it is in the case of jobs that require fewer qualifications and are less productive. In addition, intrinsically satisfying jobs are often also rewarded by higher wages and higher job security. One might object to this practice, from the point of view of intuitions about distributional fairness, that it amounts to unfairly duplicating the positive and negative rewards attached to positions within organizational hierarchies.

As the actual contribution an employee makes to the overall output of a firm or administrative public sector unit is typically impossible to measure in objective and uncontroversial terms, the meritocratic attribution of status operates predominantly through input measures, i.e., the certified skills employees have acquired (mostly) before entering a work organization. Apart from the acquisition of these skills being highly contingent upon "conditions" (endowment with talent, accessibility and quality of educational institutions, other "social mechanisms"), organizations partly reward efforts that employees have made, in the case of the median-aged employee, several decades before the (present) point in time at which they are being rewarded. Again, this mechanism cuts both ways: While academic certificates typically grant a life-long rent to employees as a return on investment in human capital, those who have failed to graduate from secondary school will have very limited chances to be ever considered for "better" jobs. Moreover, the skill requirements of the job an employee performs may or may not coincide with the skills s/he acquired at the time of her schooling or his professional training. Also, it is probably not too daring a speculation that most workers most of the time depend on skills and knowledge for the performance of their jobs that they have acquired on the job, while the human capital acquired through formal education may well be underutilized on the job. Finally, in most cases there is no objective algorithm that would allow management to derive the profile of formal skills that is "required" by a particular job; if such algorithm exists, it is typically established by legal regulation and standardization, not through managerial discretion. The answer to what one needs to be a nurse in a hospital (apprenticeship? college degree? university degree?) differs widely between national health systems, as does the job description and the division of labor between medical doctors and nurses itself. Skill "requirements" can also change with labor market conditions, with employers being both able to and interested in ratcheting-up skill requirements for given jobs when labor supply is plentiful relative to demand, a condition which tends to make skills "cheaper" to employ. Employers may also find it expedient to switch between criteria of formal skill requirements and informal measures of job experience, techniques of personality assessment, "suitability", reference letters, the reputation of former employers, networks, the evidence of social skills and desired personality traits. While reliance on formal certificates and credentials may provide a (limited) measure of meritocratic justification, such less formal criteria play an at least equally significant role in managerial practices of recruitment, promotion, and organizational stratification.

In addition to past effort and ambition that has resulted in human capital formation, rewards can be tied to perceived levels of present efforts on the job or signals concerning $f u$ ture work behavior of job candidates. The display of discipline, punctuality, engagement for the organization's objectives, loyalty towards superiors, and reliability are subjective "work attitudes" which are obviously, and perhaps increasingly, appreciated and honored by employers and managers. 
The importance of these subjective features is also indicated by the emphasis that active labor market policies and programs attach to the inculcation of these industrial virtues in order to promote the somewhat nebulous quality of "employability" of job seekers. To be sure, there are also objective measures of effort. They seem to be limited, however, to temporal aspects of work. These include chronometrical aspects ("willingness to work extra hours", working fast, spending leisure time on the acquisition of additional skills) and chronological ones ("being punctual, keeping deadlines, being ready to work night shifts" etc.). Yet the opportunity to display and practice these virtues is itself very much contingent upon the organizational structure of the tasks to be performed and the autonomy it affords.

The distinction of voluntary inputs (choice, effort, ambition) that in the liberal egalitarian discourse are being set apart from unchosen "conditions" and "luck" largely fail to make operational sense on the shop floor, in spite of its normative attractiveness. As Kymlicka (2006, p. 20) rightly observes: "There is no way in practice to implement these principles in a rigorous way. Public institutions cannot effectively track the choices/circumstances distinction" and, we might add, even less so can - nor have any reason to attempt - work organizations and their managements. While "winners" in organizational hierarchies will tend to attribute their status to their own efforts (or prudence, farsightedness, self-discipline, character etc.) and, correspondingly, that of "losers" to their lack of such qualities, losers will tend to describe themselves as being handicapped by circumstances, as having been deprived of fair opportunities, as having been discouraged or discriminated against, or working under conditions that render "effort" subjectively pointless. Moreover, they may also be inclined to perceive winners as being unfairly privileged by circumstances, such as a favorable family background and social networks.

An interesting further component of meritocratic practices of assigning bundles of differential rewards to particular jobs is the role of "responsibility" as a yardstick of desert and the attribution of status. The notion of responsibility matches the nature of tasks and of the persons that perform them. Some jobs are said to involve greater personal responsibility than others, which is usually intended to mean: If those performing them fail to apply the rules of their trade and to appropriately exert their cognitive and motivational capacities, the potential damage caused by such failure would be greater than in the case of others. Therefore, the greater the responsibility (as measured in terms of potential damage - think of an airline pilot) the greater the remuneration deserved. This reasoning assumes that "responsibility" is subjectively perceived as a kind of work disutility or burden that calls for an adequate compensation. This perception may or may not be present, which is anyway as hard to prove as any subjective assessment of (dis)utility: Perhaps the person entrusted with responsibility does not really perceive it as a burden, but as an honor, distinction, and mark of personal success - who knows or even can know? It further assumes that in the absence of such special compensation it would be either difficult to fill the position in question (because people shy away from responsible jobs unless there are special incentives) or that those who actually hold it would act less responsibly and become negligent in the performance of their task - both of which assumptions refer to counterfactuals which can at best be more or less plausible. Yet this latter proposition can only be stated (as the late Cohen [2008] argued) in the third-person perspective, not in that of the first person, i.e., a speaker speaking about herself. For that would mean to say: "In case I were to be deprived of my responsibility bonus, I would either desert my job or fail to perform it responsibly" - which is a proposition that plainly betrays a massive level of irresponsibility. Similarly and more generally, when beneficiaries of privileged status claim that conceding advantages to them will ultimately benefit the less privileged, they are not speaking about some causality in the world "out there", but about themselves: The reason that this claim is "true" is that beneficiaries are in a position to effectively decide it must be true, using a kind of blackmail in order to make it true. Such claims and propositions fail what Cohen (2008) calls the "interpersonality test": responsible action (in contrast to "effort") is not something that one can consistently turn on and off, depending on the level of reward. Nor can one justify one's own claim to privilege by threatening with one's own retaliatory power which will be deployed in case the claim is not honored.

\section{Conclusion}

My selective review of contributions from various social sciences to the explanation and justification of patterns of inequality has not resulted in a convergent perspective. This was neither my objective, nor could it be expected. Issues of distributive justice are essentially contested, and likely to remain so, given the great diversity of philosophical approaches, as well as of the interests involved. One axis of controversy is whether equality and economic performance are really conflicting values or whether, to the contrary, it is exactly egalitarian policies which can provide for "real" or "substantive" freedom and economic performance. Another set of issues concerns the normative viability and policy implications of the conditions vs. ambitions dichotomy. Furthermore, the question remains wide open as to what the most appropriate institutional site is for the promotion of equality (or rather justifiable patterns of inequality): the state and its budget, democratic citizenship, the labor market and its institutions, the educational system, the family, the busi- 
ness firm? It is exactly because there is no comprehensive answer in sight to the normative and analytical issues I have touched upon that we must see to it that the space for deliberation on these issues is not closed by false authority claims coming from any of the disciplines, doctrines, and intellectual traditions involved in it.

\section{Executive summary}

The paper represents an invited keynote address, held at a conference sponsored by the IAB. In line with this format, it does not address specific data and analysis but provides a wide-ranging overview of ongoing debates and persistent ambiguities in social philosophy, sociology, economics, and organization studies.

Social inequalities have been a core problem of the social sciences since their origin in the 19th century. The three issues are: How can they be explained, justified, and remedied (to the extent they can not be justified as fair and legitimate). Part I of the paper presents a condensed discussion of four normative philosophical arguments, ranging from individualistic-egalitarian to left-communitarian positions. In between these two extremes, we find liberal-egalitarian positions (based upon the important distinction between "conditions" vs. "ambitions" or "effort" as determinants of distributional outcomes) and the "capability perspective", as inaugurated by Sen and others, which emphasizes the normative standard of public policies which enable/empower people to realize their reasoned life plans. Here, the author explores the conceptual problems of distinguishing in operational terms between negative and positive forms of discrimination, as well as between "conditions" and "choices", as the two latter categories may well interact.

A second focus of the paper is a brief discussion of findings of empirical sociology as it proceeds from both survey and experimental data. What determines the degree to which ordinary people adhere to egalitarian, or "inequality-averse" social norms? Here, the distinction between "upward-looking" and envy-driven egalitarian norms vs. "downward-looking" and compassion-driven perspectives is introduced. Similarly, economists discuss the economic functions of unequal economic outcomes. While a majority of economists emphasize collectively beneficial incentive effects of unequal distributional outcomes, several dissenting authors are cited who provide arguments that it is, to the contrary, more egalitarian patterns of (income) distribution that can enhance overall efficiency.

Thirdly, the paper addresses the question whether or not it is the labor market itself that generates unequal outcomes in terms of three relevant bundles of variables, namely income/wealth, qualities of jobs (including work-life balance), and job/income security. The author adopts the somewhat unorthodox view that it is not the labor market that generates these distributional outcomes but the system of institutions in which the market is embedded and which are ultimately constituted by political decisions. Significant "pre-existing conditions" of labor market transactions are the educational system, institutions of social security, individual and collective labor law, and family related policies. It is argued that it is largely not the labor market, but regulatory and other public policies (or their politically determined absence) that are the ultimate causes of distributional outcomes in the above three dimensions.

The fourth and final section deals with distributional effects of managerial decisions and practices within firms and other (large scale) work organizations. The author presents arguments to the effect that economic variables (such as quantity and quality of supply and demand, marginal product, relative cost, individual productivity of workers) play at best a limited role in the determination of intra-organizational distributional rewards, thus questioning individualist and "meritocratic" justifications of pay and other status differences. These differences can neither be (fully) explained by reference to "choice" variables (such as effort, flexibility, ambition) nor by "condition" variables ("talent" and other aspects of personal "luck"), least of all in proportion to the somewhat mysterious yet widely invoked measure of "responsibility". While it thus remains an open question how differential distributional outcomes can at all be justified, it also remains an open question at which institutional level (the family?, the state budget?, industrial relations?, the educational system?) poorly justified inequalities can possibly be remedied according to any standard of distributional fairness.

\section{Kurzfassung}

Dieser Beitrag ist die schriftliche Version eines Eröffnungsvortrages, der auf einer vom IAB gesponserten Konferenz gehalten wurde. Gemäß diesem Format konzentriert sich der Beitrag nicht auf spezielle Daten und Analysen, sondern bietet einen weitreichenden Überblick über laufende Debatten und anhaltende Ambiguitäten in der Sozialphilosophie, Soziologie, Ökonomie und Organisationstheorie.

Soziale Ungleichheiten sind ein Kernproblem der Sozialwissenschaften, seit diese im 19. Jahrhundert begründet wurden. Die drei Hauptfragen sind, wie diese Ungleichheiten zu erklären, zu rechtfertigen und zu beheben sind (sofern diese sich nicht als fair und legitim rechtfertigen lassen). Teil 1 präsentiert eine zusammengefasste Diskussion über vier normative philosophische Argumente, die sich von individualistisch-egalitären bis links-kommunitaristischen Positionen erstrecken. Zwischen diesen beiden Extremen finden wir liberal-egalitäre 
Positionen (basierend auf der wichtigen Unterscheidung zwischen vorgefundenen Bedingungen vs. gewählten Niveaus von Mühe und Anstrengung als Determinanten von Verteilungsergebnissen) und den von Sen und anderen entwickelten Verwirklichungschancen-Ansatz, welcher die normative Funktion von öffentlichen Politiken betont, die es Menschen ermöglichen/sie befähigen soll, die eigenen Lebenspläne zu verwirklichen. Hier untersucht der Autor die begrifflichen Probleme der operationellen Unterscheidung zwischen negativen und positiven Formen der Diskriminierung, und zwischen „Konditionen“ und „Entscheidungen“, da die zwei letzteren Kategorien durchaus miteinander interagieren können.

Einen zweiten Schwerpunkt bildet die kurze Erörterung der Ergebnisse der empirischen Soziologie, die sowohl auf Umfrage- als auch auf Untersuchungsdaten basieren. Was bestimmt inwieweit normale Menschen, sich an egalitäre oder „Ungleichheit-abgeneigte“ Sozialnormen zu halten? An dieser Stelle wird die Unterscheidung zwischen ,nach oben schauenden" und vom Neid getriebenen egalitären Normen vs. "nach unten schauenden" und vom Mitgefühl getriebenen Ansätzen eingeführt. Auf ähnliche Art und Weise diskutieren Wirtschaftswissenschaftler die ökonomischen Funktionen von ungleichen wirtschaftlichen Ergebnissen. Während die Mehrheit der Wirtschaftswissenschaftler die für die Gesamtheit positiven Anreizwirkungen der ungleichen Verteilungsergebnisse betonen, werden in diesem Abschnitt mehrere abweichende Autoren zitiert, die argumentieren, dass es im Gegenteil eher egalitäre Muster der (Einkommens-) Verteilung sind, die die Gesamteffizienz steigern können.

Drittens setzt sich der Beitrag mit der Frage auseinander, ob der Arbeitsmarkt selber ungleiche Ergebnisse generiert, bezogen auf drei relevante Variablenbündel, nämlich Einkommen/Wohlstand, Arbeitsbedingungen (einschl. WorkLife-Balance), und Arbeitsplatz- und Einkommenssicherheit. Der Autor vertritt die etwas unorthodoxe Position, dass der Arbeitsmarkt nicht für diese Verteilungsergebnisse verantwortlich ist, sondern das System der Institutionen, in dem der Markt eingebettet ist und das letztendlich aus politischen Entscheidungen besteht. Signifikante ,objektive" Voraussetzungen der Arbeitsmarkttransaktionen sind das Bildungssystem, Institutionen der sozialen Sicherheit, Individualarbeitsrecht und kollektives Arbeitsrecht sowie familienbezogene Politiken. Es wird argumentiert, dass die Verteilungsergebnisse in den drei oben erwähnten Dimensionen vorwiegend nicht dem Arbeitsmarkt, sondern letztendlich Regulierungs- und anderen öffentlichen Politiken (oder deren politisch bedingtem Nichtvorhandensein) zuzuschreiben sind.

Der letzte Abschnitt beschäftigt sich mit den verteilungsbezogenen Auswirkungen von betriebswirtschaftlichen Entscheidungen und Praktiken in Firmen und anderen (größeren) Arbeitsorganisationen. Der Autor bringt Argumente vor, die besagen, dass ökonomische Variablen (wie die Quantität und Qualität des Angebots und der Nachfrage, das Grenzprodukt, Relativkosten und die Einzelproduktivität unter Arbeitern) höchstens eine begrenzte Rolle in der Festlegung von organisationsinternen Verteilungsbelohnungen spielen, und stellt dabei individualistische und ,leistungsorientierte“ Rechtfertigungen für Lohn- und andere Statusunterschiede infrage. Solche Unterschiede sind weder (völlig) durch das Verweisen auf „Entscheidungsvariablen“ (wie Mühe, Flexibilität, Ambition) noch durch „Konditionsvariablen“ (,Talent“ und andere Aspekte des persönlichen „Glücks“) zu erklären, vor allem nicht im Verhältnis zu dem etwas mysteriösen aber oft zitierten Faktor der ,Verantwortung“. Während die Frage, wie ungleiche Verteilungsergebnisse überhaupt zu rechtfertigen sind, offen bleibt, gilt dies ebenfalls für die Frage, auf welcher institutionellen Ebene (Familie? Staatsbudget? industrielle Beziehungen? Bildungssystem?) schwer zu rechtfertigende Ungleichheiten nach irgendeinem Standard der Verteilungsgerechtigkeit zu beheben sind.

\section{References}

Alesina, A., Giuliano, P.: Preferences for redistribution. NBER Working Paper 14825, Cambridge, MA (2009)

Anderson, E.S.: What is the point of equality? Ethics 109, 287-337 (1999)

Cohen, G.A.: Rescuing Justice and Equality. Harvard University Press, Cambridge, MA (2008)

Dworkin, R.: Sovereign Virtue. The Theory and Practice of Equality. Harvard University Press, Cambridge, MA (2000)

Fehr, E., Naef, M., Schmidt, K.M.: Inequality aversion, efficiency, and maximin preferences in simple distribution experiments: Comment. AER 96(5), 1912-1917 (2006)

Galbraith, J., Conceicao, P., Ferreira, P.: Inequality and unemployment in Europe: The American cure. New Left Rev. 237, 28-51 (1999)

Halliday, S.: Equality of opportunity. Roemer's synthesis. http://simon. d.halliday.googlepages.com/EqOp.pdf (2008). Accessed $2 \mathrm{Apr}$ 2010

Jäntti, M., Bratsberg, B. et al.: American exceptionalism in a new light: A comparison of intergenerational earnings mobility in the nordic countries, the United Kingdom and the United States. IZA Discussion Paper No. 1938, Bonn (2006)

Kymlicka, W.: Left liberalism revisited. In: Sypnowich, C. (ed.) The Egalitarian Conscience. Essays in Honour of G.A. Cohen, pp. 9-35. Oxford University Press, Oxford (2006)

Miller, D.: Principles of Social Justice. Harvard University Press, Cambridge, MA (1999)

New Economics Foundation: A bit rich. Calculating the real value of different professions. http://www.neweconomics.org/sites/ neweconomics.org/files/A_Bit_Rich.pdf (2009). Accessed 2 Apr 2010

Nozick, R.: Anarchy, State, and Utopia. Basic, New York (1974)

Offe, C.: Industry and Inequality. The Achievement Principle in Work and Social Status. Edward Arnold, London (1976)

Offe, C.: Basic income and the labor contract. Anal. Krit. 31(1), 49-79 (2009) 
Pierik, R., Robeyns, I.: Resources versus capabilities: Social endowments in egalitarian theory. Polit. Stud. 55, 133-152 (2007)

Roemer, J.: Equality of Opportunity. Harvard University Press, New York and Cambridge, MA (1998)

Sen, A.: Equality of What? In: McMurrin, S.M. (ed.) The Tanner Lectures on Human Values, vol. 1. University of Utah Press, Salt Lake City (1980)

Sen, A.: Inequality Re-examined. Clarendon Press, Oxford (1992)

Claus Offe, born 1940, was (until his retirement in 2005) Professor of Political Science at Humboldt University, Berlin, where he held a chair of Political Sociology and Social Policy. He earned his PhD (Dr. rer. pol.) at the University of Frankfurt (1968) and his Habilitation at the University of Constance. From 2006 to present he has been teaching at the Hertie School of Governance, a private professional school of public policy, where he holds a chair of Political Sociology. Previous positions include professorships at the Universities of Bielefeld and Bremen, where he served as director of the Center of Social Policy Research. He has held research fellowships and visiting professorships in the USA, Canada, Australia, Hungary, Poland, Austria, Italy, and the Netherlands. He was awarded an honorary degree by the Australian National University in 2007. His fields of research include democratic theory, transition studies, EU integration, and welfare state and labor market studies. He has published numerous articles and book chapters in these fields, a selection of which has recently been reprinted as Herausforderungen der Demokratie. Zur Integrations- und Leistungsfähigkeit politischer Institutionen (2003). Book publications in English include Varieties of Transition (1996), Modernity and the State: East and West (1996), Institutional Design in Post-Communist Societies (1998, with J. Elster and U.K. Preuss) and Reflections on America. Tocqueville, Weber, and Adorno in the United States (2006). E-mail: offe@hertie-school.org 